\title{
A quantitative framework for evaluating the sustainability of Irish potato cropping systems after the landmark agrarian reform in Zimbabwe
}

\author{
O. Svubure, P.C. Struik, A.J. Haverkort and \\ J.M. Steyn
}

Abstract: Frameworks to evaluate the sustainability of cropping systems in developing countries are scarce. This study proposes a framework to select easily quantifiable indicators that can be used to assess and communicate the sustainability of cropping systems in developing countries. The widely accepted social, economic and environmental dimensions of sustainability were covered using predefined criteria from which the indicators were then drawn. An initial list of indicators was established based on literature review and expert opinion, and through filtering reduced to 16 core indicators. Using the case of Irish potatobased cropping systems, a grower survey was conducted to collect data on production practices in four different cropping systems. The survey data were then used to calculate the sustainability indicators expressed as resource use efficiencies based on actual potato yields. The survey data also served as input into the Cool Farm Tool - Potato model to estimate greenhouse gas emissions from farm operations involved in potato production. With the help of local agricultural extension officers, focus group discussions were held with farmers of each production system to decide on sustainable and unsustainable indicator threshold levels. The participatory nature of the framework involving farmers and local extension officers secured buy-in from key stakeholders important for operationalization, monitoring and evaluation.

Keywords: sustainability indicators; benchmark; sustainability dimensions; Cool Farm Tool - Potato model; Zimbabwe

O. Svubure (corresponding author) is with the Department of Irrigation and Water Engineering, Chinhoyi University of Technology, PB 7724, Chinhoyi, Zimbabwe, and the Centre for Crop Systems Analysis, Wageningen University and Research Centre, 6700 AK Wageningen, The Netherlands. E-mail: osvubure@cut.ac.zw; osvub@yahoo.com.P.C. Struik is also with the Centre for Crop Systems Analysis at Wageningen University and Research Centre. A.J. Haverkort is with Plant Research International, Wageningen University and Research Centre, and the Department of Plant Production and Soil Science at the University of Pretoria, South Africa. J.M. Steyn is also with the Department of Plant Production and Soil Science at the University of Pretoria. 
The need for sustainability in agricultural production systems is now widely recognized. Sustainable agricultural systems are robust and continue over an indefinite period while delivering favourable economic, social and environmental outcomes (Pretty, 2007). The thrust towards sustainability of wide-ranging agricultural or food systems needs to be monitored and evaluated regularly. Consequently, the question of which framework or protocol to use to select easily quantifiable indicators arises. Indicators can be viewed as quantitative measurements against which the performance of certain management interventions can be assessed (Pannell and Glenn, 2000). Effective indicators communicate technical and complex phenomena in a quantitative manner that targeted users can readily understand and relate to (Ramos and Caeiro, 2010). In this way, stakeholders can translate sustainability indicators into policy and subsequently into action. Indicators also serve to provide development trends or indicate trajectory tracking progress (Patterson, 2006). Therefore, this implies that a benchmark is needed against which the indicator can be evaluated. The benchmarks or reference values for each indicator can include results from experimental plots under the best treatments, data from the best performing farmers or technologies, or comparisons with neighbouring countries.

Another important dimension is the participation of end-user stakeholders in indicator conceptualization and development. Such involvement helps capacitate the users, so that they will most likely appreciate and apply the indicators (Mascarenhasa et al, 2014). Breckenridge et al (1995) argued that indicators for natural resource management had been commonly identified, evaluated and selected by researchers. This renders the indicators less meaningful because the local communities will require training and equipment to use them. Such important capacity building is rarely provided for these communities. In order to avoid this trap, the meaningful participation of all stakeholders in the entire process of indicator identification, evaluation and selection is essential (Reed and Dougill, 2002). However, involving stakeholders and their interest groups to develop sustainability indicators is a complex process, even for experts (Vaidya and Mayer, 2014). There is potential for conflicting perceptions and diverse socioeconomic preferences rendering the process a challenge (Johnson, 1999). Notwithstanding such challenges, participatory approaches are emerging as more holistic methods for assessing sustainability and developing indicator sets (Vaidya and Mayer, 2014).

While sustainability assessments are increasingly seen as important tools to assist the transition towards sustainable development, very few assessment processes are being implemented globally (Pope et al, 2004). Notably in the developing world, use of the many tools or methods developed to assess agricultural sustainability is hampered by lack of data (König et al, 2012). In the last decade, scientists have proposed many integrated frameworks to aid decision making in sustainability assessment processes (Paracchini et al, 2011; Vaidya and Mayer, 2014). However, the main focus - especially in the developing world - has been on land use and natural resource management (Reed and Dougill, 2002; Reidsma et al, 2011;
König et al, 2012). Few studies, though, have focused on cropping sustainability frameworks, except, for example, in Bangladesh (Roy and Chan, 2012) and Benin in SubSaharan Africa (Yegbemey et al, 2014).

Zimbabwe, like most countries in southern Africa, has a very strong smallholder cropping system based on maize (Zea mays), and its sustainability has received increased research attention over the last two decades (Waddington et al, 2007). Communal area farming in Zimbabwe is practised on about $50 \%$ of the total land area of about 390,000 km² (Campbell et al, 1997). Research efforts in the smallholder maize-based cropping systems have centred on soil fertility (Waddington et al, 2007), soil organic matter (Swift and Woomer, 1993), soil erosion (Elwell, 1984) and crop yield as proxies for sustainability indicators. However, no base levels of each of these indicators were selected as benchmarks to assess progress, and no relevant early-warning information was provided on the environmental, economic and social state of this system. In order to address these concerns, there is a need to define a framework to assess the sustainability of cropping systems in Zimbabwe that can be applied to develop the most relevant indicators to guide decision making by stakeholders. A practical application is provided here through the example of Irish potato-based (Solanum tuberosum) cropping systems in the Eastern Highlands of Zimbabwe.

\section{Study area}

Zimbabwe undertook a fundamental land reform programme at the turn of the millennium when about $96 \%$ of the original 12.5 million ha of large-scale commercial farmland in 1980 was taken up for resettlement by 2010 (Moyo, 2011). Two resettlement models were used: the A1 model, in which beneficiary households were allocated about 6 ha of arable land and communal grazing land; and the A2 model, with self-contained farm units ranging from about 35 to 300 ha, depending on the agro-ecological environment. In Nyanga district (Figure 1), the resettled farmers have since started growing potatoes, adding growers to the existing communal area and the few remaining large-scale commercial farmers (Svubure et al, 2015).

Substantial growth in the Irish potato-cropped area, output and yield has been witnessed over the last decade. Total annual production increased steadily from about $36,500 \mathrm{t}$ in 2001 to $>58,000 \mathrm{t}$ in 2013 due to increases in both cropped area and yield (FAOSTAT, 2013). However, experts estimate annual potato area at around 6,000 ha and annual production at nearly 120,000 $\mathrm{t}$ (Ackerman, personal communication, 2013; Manzira, personal communication, 2013). Irish potato has become the most important horticultural crop in the country and the third most important carbohydrate food source after maize and wheat (The Herald, 2011). Stakeholders in the potato industry have an ambitious plan to increase the cropped area to 30,000 ha in the medium term (The Herald, 2011; Ackerman, personal communication, 2013). This is motivated by rising demand and assurance of sufficient seed potato quantities from seed companies (The Herald, 2011; Ackerman, personal communication, 2013). In addition, the government provided a major policy boost to the industry by declaring Irish potato a national strategic food 


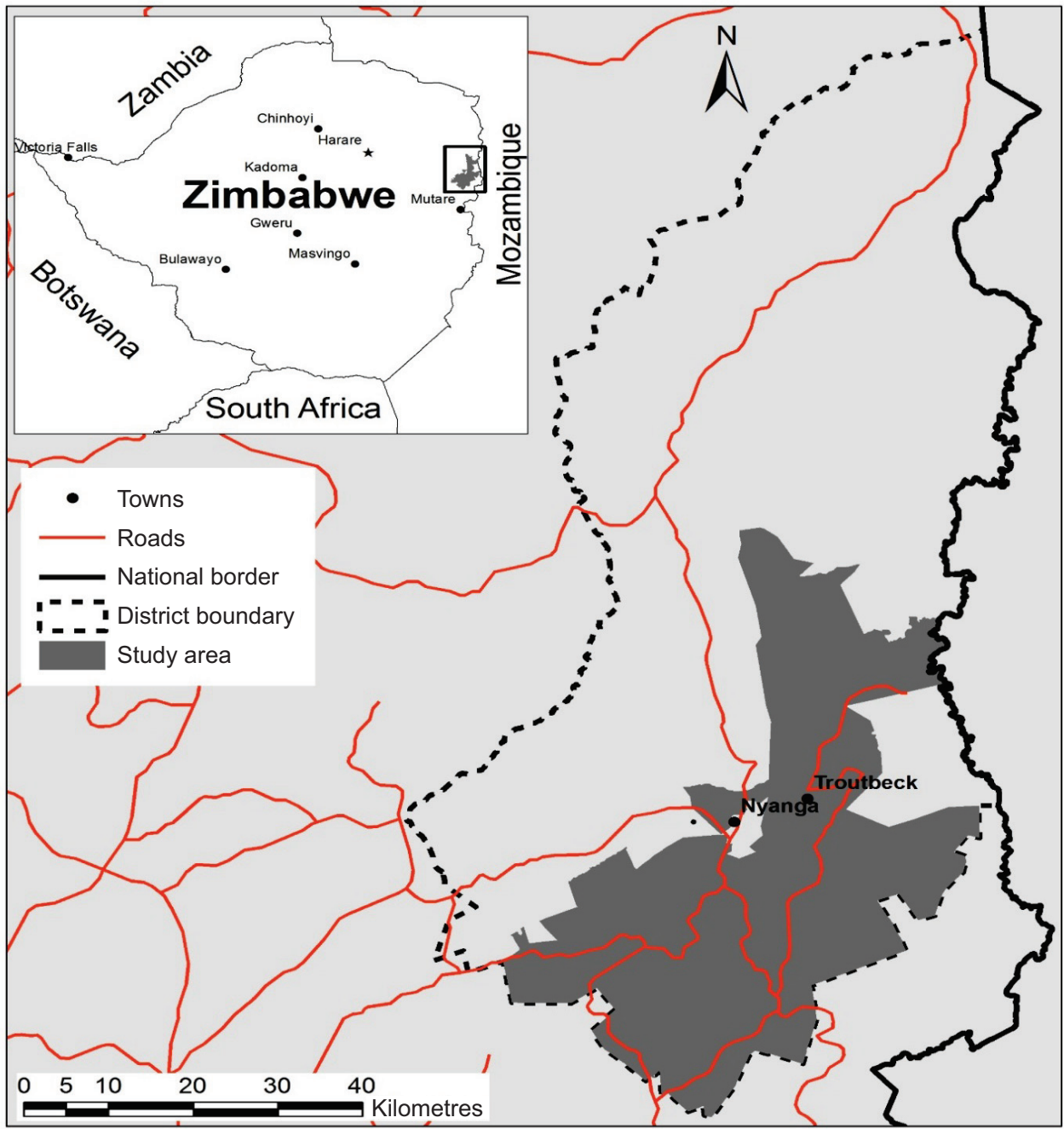

Figure 1. Nyanga district in Zimbabwe showing the location of the study area.

security crop (The Herald, 2012). Together with maize, potato is now included in the government input and mechanization support schemes (The Herald, 2012).

The cropping system in southern Nyanga (Figure 1) is Irish potato-based, making the area a natural choice for this study. Irish potato is the staple food crop in this area. In terms of rainfall and temperature, the Eastern Highlands, which cover virtually the whole of southern Nyanga, provide the best agro-ecological environment for potato production in Zimbabwe. The high elevations > 1,800 $\mathrm{m}$ above mean sea level provide the Eastern Highlands with a characteristic temperate microclimate and vegetation. Using average climatic data for the period 1985 through 2010, mean monthly minimum temperature ranges from $5^{\circ} \mathrm{C}$ in July to $13^{\circ} \mathrm{C}$ in January, whereas mean monthly maximum temperature ranges from $17^{\circ} \mathrm{C}$ to $23^{\circ} \mathrm{C}$ in July and November respectively (Figure 2). The rainy season runs from October to April, but the Eastern Highlands receive rainfall throughout the year, with monthly precipitation ranging from $14 \mathrm{~mm}$ (August) to $340 \mathrm{~mm}$ (January) (Figure 2). Potato is generally grown throughout the year; supplementary irrigation is applied during the drier winter months. However, the following cropping calendar is typical: summer crop (November through March), early winter crop (February through May) and a late winter crop planted in June/July or early August in frost-prone areas and harvested in November/December.

Four potato-based cropping systems can be distinguished in Nyanga district, mainly due to the effect of management and mechanization levels. These are the communal and A1 resettlement (smallholder) systems, and the large-scale commercial and A2 resettlement (large-scale) systems (Svubure et al, 2015). However, within each production system, heterogeneity may exist, as the mix of opportunities available to one farming household may be quite different from that available to another, leading to correspondingly different cropping management practices (Campbell et al, 1997). Some A2 resettlement and large-scale commercial farmers are located in a designated quarantine area in southern Nyanga (Figure 1). It is an isolated zone created by a statutory instrument in 1956 when the government started a potato breeding programme, and is responsible for the initial potato seed multiplications (Joyce, 1982). No other solanaceous plants are allowed in this area so as to maintain disease-free tubers. The seed potato is rainfed 


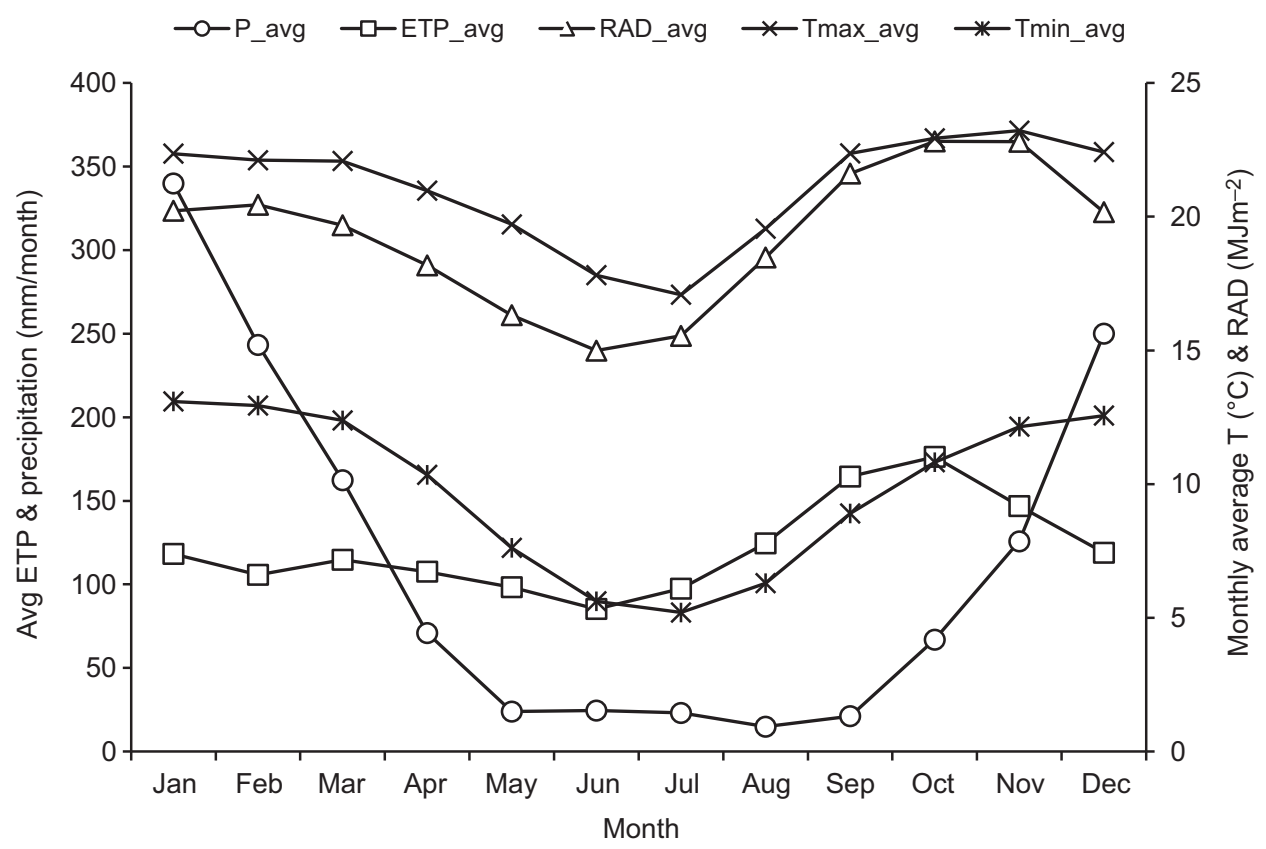

Figure 2. Monthly average precipitation (P), potential evapotranspiration (ETP), minimum temperature (Tmin), maximum temperature (Tmax) and radiation (RAD) in Nyanga Eastern Highlands of Zimbabwe, using climate data from 1985 to 2010.

Source: Meteorological Services Department of Zimbabwe.

because of the risk of bacterial wilt from the soil-borne bacterium Ralstonia solanacearum, the causal organism of brown rot which can be found in irrigation water sediment. For this reason, quarantine area growers do not have irrigation facilities (Ackerman, personal communication, 2012).

\section{Sustainability framework}

Drawing on the concept of an expert-assisted participatory approach (Vaidya and Mayer, 2014), the cropping systems sustainability assessment framework was developed (Figure 3). This involves stakeholder participation in the entire process of indicator identification, evaluation and selection, with the help of experts. In this study, two types of stakeholder groups were involved: end-users (farmers) and expert stakeholders. Involving farmers (end-users) in the process was important to ensure that the indicators selected accurately measured what was locally relevant. Besides, engagement of local farmers helps build community capacity to address future sustainability challenges or other challenges requiring a community-based approach (Fraser et al, 2006). In the expert stakeholder group, participants were drawn from both the private and public sectors with knowledge and influence on the Irish potato sector in Zimbabwe (Santana-Medina et al, 2013). The proposed framework is meant to be simple to enable farmers to apply it themselves with limited input from outside organizations such as the government extension agency, Agritex, which is mandated to offer free advisory services to the farming community. For example, farmers should be able to measure actual potato yield, plus input use, and keep records in order to monitor changes over time. The framework described is composed of six steps; while it

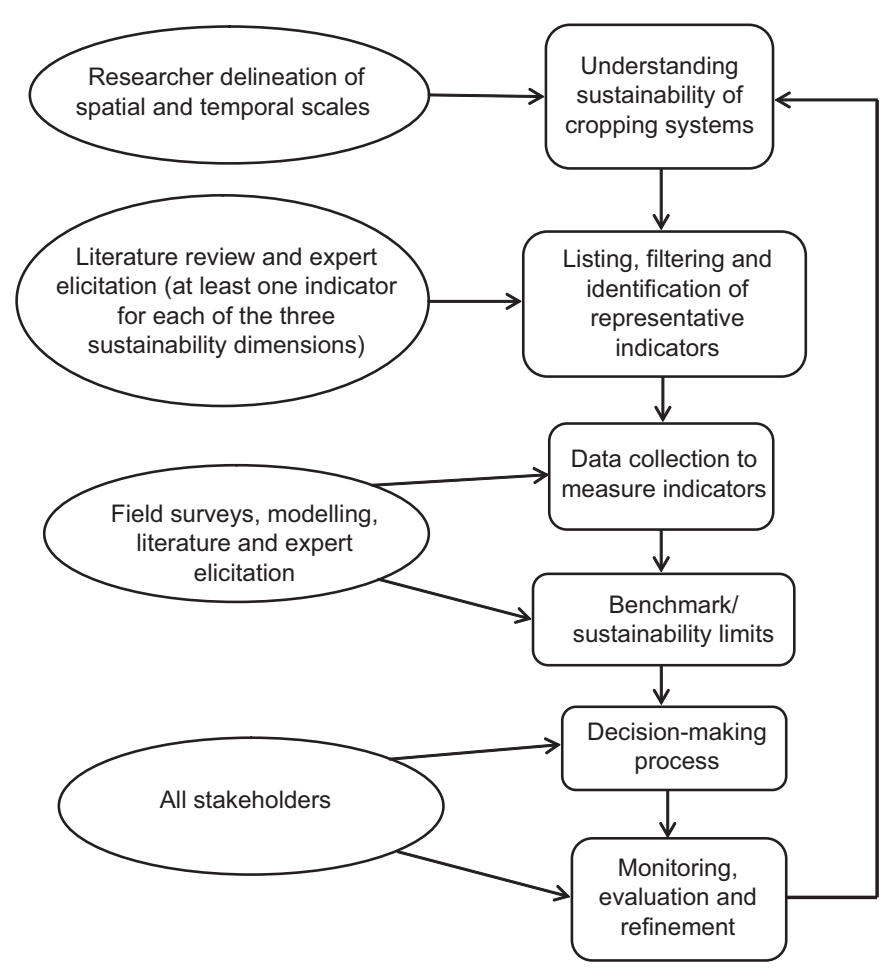

Figure 3. Framework for evaluating the sustainability of Irish potato cropping systems in Zimbabwe.

incorporates scientific issues, these can simultaneously aid policy making and action by end-users.

The paper is organized as follows: first a description of the proposed framework (Figure 3) is provided. The case study area and application of the framework in southern 
Nyanga district are then presented. Finally, the results, together with key conclusions, are described.

\section{(i) Understanding sustainability of cropping systems}

The initial step involved defining the spatial and temporal scales of analysis. Perhaps even more important than an indicator of condition in a system, is the management practice that yields the condition. Campbell et al (1997) argued that cropping systems in Zimbabwe could be distinguished by cultural practices, technology level and socio-political and economic circumstances. For example, the smallholder systems are markedly different from the large-scale systems, even when located adjacent to each other under the same biophysical conditions. Also, some heterogeneity exists within each cropping system due to differences in access to resources (Campbell et al, 1997). This leads to different approaches in production practices such as input use. Nevertheless, the different production systems are still of interest as spatial scales in sustainability assessments. While the objectives and criteria for selecting indicators remain the same, the targets and timescales to achieve them will differ.

Sustainability entails indefinite continuity, but circumstances change, requiring revision of indicator targets over time. Hence the timescale boundaries were also discussed during this first step in the framework.

\section{(ii) Identification of representative indicators}

The second step involved listing possible indicators and filtering them to identify the most relevant. Based on literature review and expert elicitation, the indicators were categorized into environmental, economic and social dimensions. For each dimension, the criteria for indicator selection included ease of measurability (Gómez-Limón and Sanchez-Fernandez, 2010; Roy and Chan, 2012; van Asselt et al, 2014) and indicator responsiveness to changes in management practices or natural variability (Campbell et al, 1997).

\section{(iii) Data collection}

Field surveys and expert elicitation were undertaken to collect all data relevant for computing the indicators.

\section{(iv) Benchmark/sustainability limits}

Benchmark or sustainability limits were defined, against which the indicators were evaluated. Relevant simulation models can be used to set benchmarks or performance limits under different crop production scenarios. If the models cannot provide limits for certain indicators, government policy targets or legal limits can be used. Another alternative is to use the best performance available as the benchmark or sustainability limit, as applied by Haverkort et al (2009) in a similar study. Stakeholder consensus on a sustainable limit and expert elicitation are other possible approaches. In this study, the sustainability indicators were expressed as resource use efficiencies based on actual yields; indicator values below the average were considered unsustainable.

\section{(v) Decision-making process}

This step involved indicator selection by stakeholders (farmers and extension officers) with help from experts. The role of researchers was mainly to coordinate the focus group discussions towards a consensus. Several assessments on cropping sustainability convert the data of base indicators into indices or scores and aggregate them into composite indicators as overall evaluation of performance (Gómez-Limón and Sanchez-Fernandez, 2010; Yegbemey et al, 2014; van Asselt et al, 2014). Gómez-Limón and Sanchez-Fernandez (2010) warned researchers to use such indices with caution, asserting that a single measure cannot accurately appraise agricultural performance. However, there are advantages and limitations in the use of composite indicators (Saisana and Tarantola, 2002). In the proposed framework described here, the indicators were expressed as resource use efficiencies. Once the indicator values were established (Step 3), the decisionmaking process established the desired levels of resource use efficiency, which represented the desired level of sustainability.

\section{(vi) Monitoring, evaluation and refinement}

Grower performance was evaluated to monitor progress towards attaining sustainability. Refinement is an integral part of continuous monitoring and the evaluation process to improve the framework as it develops in practice.

Using a crop production ecology approach for sustainable cropping, Haverkort et al (2009) described how sustainability indicator values expressed as resource use efficiency might move from unacceptably low values to sustainable levels over time. In this framework, a similar approach was proposed in which a grace period was allowed for growers with unsustainable indicator values to attain sustainability. While some growers can evaluate themselves, the Agritex agency was expected to help the majority of growers. For example, at the end of each season, the actual potato yield of each grower was measured and compared with the unsustainable threshold. The ultimate objective was continuous improvement of the farmer threshold.

\section{Case study}

The data collection process included first listing relevant indicators through a literature review and expert elicitation process, followed by conducting a grower survey to establish the potato production practices in the different systems. The grower survey data were first used to calculate the sustainability indicators expressed as resource use efficiencies based on the actual yields, and second as input data to the Cool Farm Tool (CFT) - Potato model (Haverkort and Hillier, 2011). The CFT - Potato model was used to estimate greenhouse gas (GHG) emissions from farm operations involved in potato production. Finally, with help from local extension officers, focus group discussions were held with growers of each production system to decide on the pilot indicators including the associated threshold levels of sustainability. For each dimension of sustainability, relevant indicators were listed. The panel of experts was drawn from both the public agricultural service and private institutions in the potato sector. Four experienced agricultural extension officers from the government extension agency, Agritex, were consulted. The potato breeder from the government Crop Breeding Institute (CBI) and staff from the Nyanga Experiment Station were also consulted. Other key 
experts included a prominent, large-scale commercial seed potato grower from the quarantine area and a representative from the seed potato cooperative. Indicators chosen were those that could be computed easily from the data provided by the growers.

Grower data included land preparation, planting, input use, inputs cost estimate, weed and pest management, water management, energy use, harvesting and marketing. Selection of growers for the survey was limited to those with a minimum of five years' continuous potato farming experience. The sample included three large-scale commercial growers and four A2 resettlement growers from the quarantine area where only 21 out of 27 growers were active (Ackerman, personal communication, 2012). A further 18 communal area growers, five A1 resettlement growers and one of the four remaining large-scale commercial growers, all outside the quarantine area, completed the survey. Agritex officials estimated the A1 resettlement growers to number $<100$ in Nyanga, while over 1,500 communal area households plant about 800 ha of potato annually (Svubure et al, 2015).

The CFT - Potato model as described by Haverkort and Hillier (2011) was used to estimate GHG emissions from operations undertaken in potato production, from the seed material through storage of the harvested potato product. The model output reports the factors or farm operations and their respective estimates of GHG emissions $\left(\mathrm{kg} \mathrm{CO}_{2} \mathrm{eq} / \mathrm{t}\right)$ and sums them into a single value. Each grower dataset was run separately and the mean GHG emission for each activity computed for each production system. After calculating all indicators for each farmer, focus group discussions were conducted following guidelines suggested by Ritchie and Lewis (2012). The focus group discussions decided on the indicators to use on each dimension of sustainability including the threshold levels. For each production system, separate focus group discussions were held. The group discussions were comprised of the farmers, local extension officers and researchers. Three meetings were held for the communal area production systems, one in each of the three different locations. For the other production systems, one meeting was held for each system, since fewer farmers were involved in these cases.

\section{Results}

One of the initial steps in the framework was to choose indicators that would cover the three dimensions of sustainability. The criteria for each were defined, from which in turn the indicators were derived (Table 1). A total of 16 indicators were selected from an initial larger screening list compiled from the literature review and discussions with the key experts. By combining these indicators with the grower survey data, the mean indicator values were calculated for each production system (Table 2).

The average potato yield, produce price and gross margin per dollar total variable cost (TVC) were chosen as the sustainability indicators associated with land productivity. The grower survey showed that the average yield ranged from $8 \mathrm{t} /$ ha in the $\mathrm{A} 1$ resettlement to $23 \mathrm{t} / \mathrm{ha}$ in the large-scale commercial production system (Table 2). Within the different production systems, variations in yield were observed, with the largest range of $37 \mathrm{t} / \mathrm{ha}$ reported in the communal area (Table 2). This wide range suggests the existence of unsustainable yield levels by growers in the lower part of the range. The produce (farm-gate) prices ranged from US $\$ 0.4$ to $0.8 / \mathrm{kg}$ of potato across all systems, whereas the return invested ranged from US $\$ 0.28$ to 1.17 (Table 2). Average production costs were computed using the general production practices and input use from the grower interviews. Using a blend

Table 1. Summary of dimensions of sustainability and their respective criteria and indicators for assessing sustainability of Irish potatobased cropping systems in Nyanga district, Zimbabwe.

\begin{tabular}{|c|c|c|}
\hline Dimension of sustainability & Criteria & Indicator \\
\hline Economic & Land productivity/profitability & $\begin{array}{l}\text { Yield (t/ha) } \\
\text { Produce price (US\$/kg) } \\
\text { GM/US\$1 TVC }\end{array}$ \\
\hline \multirow[t]{3}{*}{ Environment } & GHG emission reduction & $\begin{array}{l}\text { GHG emission }\left(\mathrm{kg} \mathrm{CO}_{2} \mathrm{eq} / \mathrm{t}\right) \\
\text { GHG emission }\left(\mathrm{kg} \mathrm{CO}_{2} \mathrm{eq} / \mathrm{ha}\right)\end{array}$ \\
\hline & Minimal use of natural resources & $\begin{array}{l}\text { Yield (t potato/ha) } \\
\text { Nitrogen use (g potato/g N) } \\
\text { Phosphorus use (g potato/g P) } \\
\text { Potassium use (g potato/g K) } \\
\text { Irrigation water use (g potato/l) }\end{array}$ \\
\hline & Environmental impact of biocides & $\begin{array}{l}\text { Fungicide (kg potato/g a.i.) } \\
\text { Insecticide (kg potato/g a.i.) } \\
\text { Nematicide (kg potato/g a.i.) } \\
\text { Herbicide (kg potato/g a.i.) } \\
\text { Rotation (years) }\end{array}$ \\
\hline \multirow[t]{2}{*}{ Social } & Farmer livelihood & GM/US\$1 TVC \\
\hline & Farmer community participation & $\begin{array}{l}\text { Field discussion days (number/year) } \\
\text { Farmer training meetings (number/year) }\end{array}$ \\
\hline
\end{tabular}

Note: $\mathrm{GM}=$ gross margin $; \mathrm{TVC}=$ total variable cost; $\mathrm{CO}_{2}$ eq = carbon dioxide equivalent; a.i. = active ingredient; $\mathrm{N}=$ nitrogen; $\mathrm{P}=$ phosphorus; $\mathrm{K}=$ potassium. 


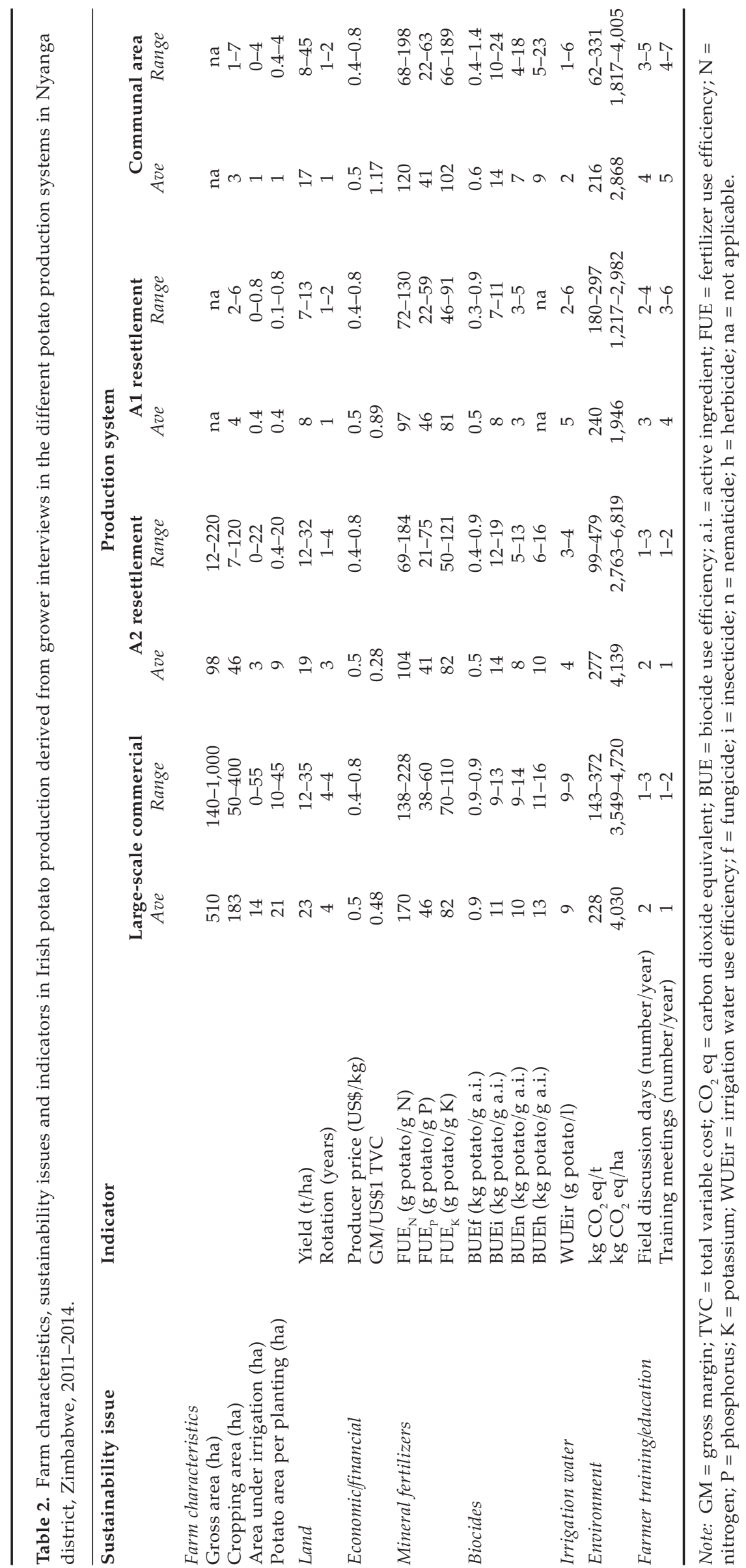


of farm-gate price and the actual yield of each grower, the gross margin of each grower was calculated, from which the returns per dollar invested were derived. Although the return was high in the smallholder A1 resettlement and communal area production systems, incomes remained low because of the low volumes of crop traded due to low yield levels.

The environmental criteria included GHG emission reduction, minimization of extraction or use of natural resources and the impact of biocide use on the environment (van Asselt et al, 2014). The yield data from the grower survey were used to calculate indicator values of GHG emissions, nutrients, biocides and water expressed as resource use efficiencies (Table 2). Mean GHG emission as estimated by the CFT - Potato model ranged from 216 $\mathrm{kg}$ of $\mathrm{CO}_{2} \mathrm{eq} / \mathrm{t}$ in the communal area to $277 \mathrm{~kg}$ of $\mathrm{CO}_{2} \mathrm{eq} / \mathrm{t}$ in the A2 resettlement system. Variations within the production systems were observed; the highest was in the A2 resettlement system, where it ranged from 99 to $479 \mathrm{~kg}$ of $\mathrm{CO}_{2} \mathrm{eq} / \mathrm{t}$. Mean GHG emissions estimated in $\mathrm{kg}$ of $\mathrm{CO}_{2}$ $\mathrm{eq} / \mathrm{ha}$ ranged from $1,946 \mathrm{~kg}$ of $\mathrm{CO}_{2} \mathrm{eq} / \mathrm{ha}$ in the $\mathrm{A} 1$ resettlement to $4,139 \mathrm{~kg}$ of $\mathrm{CO}_{2} \mathrm{eq} / \mathrm{ha}$ in the $\mathrm{A} 2$ resettlement system. Variations within the production systems were similarly observed, the highest again in the A2 resettlement system, where it ranged from 2,763 to $6,819 \mathrm{~kg}$ of $\mathrm{CO}_{2} \mathrm{eq} / \mathrm{ha}$. Such a wide range suggests inefficient grower practices, especially among growers in the upper part of the range. The major driver of emissions was a combination of high $\mathrm{N}$ use (data not shown) and low potato yield. A wide variation in mineral fertilizer use efficiency among all the sample growers was observed, ranging from 68-228 $\mathrm{g}$ of potato/g of $\mathrm{N}, 21-75 \mathrm{~g}$ of potato/g of $\mathrm{P}$, and $46-189 \mathrm{~g}$ of potato/g of $\mathrm{K}$ (Table 2). High mineral fertilizer use was reported, and this, coupled with the correspondingly low yields, suggests that not all fertilizer applied was being utilized by the crop. Biocide use in potato production in Zimbabwe is high, with fungicides most frequently used in terms of both the number of sprays and quantities applied during the crop growth cycle (Svubure et al, 2015). A wide variation in biocide use efficiency was recorded among all growers, ranging from non-use in the A1 resettlement to $24 \mathrm{~kg}$ of potato $/ \mathrm{g}$ a.i. of insecticide in the communal area production system (Table 2 ).

Potato crop rotation was another important indicator under the environmental dimension of sustainable cropping. Growing potato continuously on the same piece of land leads to pests and disease inocula build-up that will require biocide spraying to prevent causing environmental concerns and increasing production costs. Potato rotation among the sample growers ranged from one to four years across all production systems. Minimization of irrigation water extraction was another important criterion. The indicator 'water use efficiency' was chosen to evaluate irrigation water use. A wide variation in irrigation water use efficiency was reported among the sample farmers, ranging from $1 \mathrm{~g}$ of potato/ 1 in the communal area to $9 \mathrm{~g}$ of potato/ 1 in the large-scale commercial production system. The temperate climatic pattern with humid and high-rainfall conditions in the Nyanga Eastern Highlands reduces the need for supplemental irrigation (Figure 2). However, unexpectedly high irrigation water use is reported in the Nyanga Eastern Highlands, mainly because surface irrigation water is abundant and because the majority of the growers' irrigation systems are gravity-fed, incurring no energy costs, hence the tendency to over-irrigate (Svubure et al, 2015). The over-application of irrigation, coupled with low yields, explains the generally low water use efficiencies.

The farmer's livelihood from potato cropping and participation in community farming-related activities were defined as the criteria for the social dimension of sustainable cropping. The gross margin per dollar of TVC from potato cropping, mentioned previously, and the number of field discussion days and training meetings attended per year by any member of the farm family were chosen as the indicators of sustainable cropping under the social dimension. Field discussion days are arranged by farmer groups in coordination with the local agricultural extension officer. The host farmer showcases good agricultural practice for the community to learn from.

Agrochemical companies and potato buyers also participate in the field discussion days, mainly as an opportunity to advertise their products and services. Attendance at such field discussion days varied among the sample farmers from once per year in the large-scale commercial to five times per farmer per year in the communal area production system. Farmer training meetings followed a similar trend in which attendance varied from one to seven times per farmer per year. These training meetings are in most cases organized by the local agricultural extension officer. Facilitators from outside the area are sometimes invited to provide training on specific topics. The highest number of training meetings was recorded in the communal area system in which, on average, five meetings were attended. The government extension service is mainly focused on smallholder systems rather than on the large-scale systems.

\section{Proposed sustainability indicator thresholds}

The mean indicator values and range within each production system were in most cases used as the basis to set the sustainability indicator thresholds. Indicator values below the average value in each production system were considered unsustainable, while the upper (or maximum) values represented the best practice; these were set as medium to long-term minimum sustainable thresholds. Indicator values in between the unsustainable and sustainable thresholds were regarded as transitionary, and a grace period (usually two to four years) was set during which affected growers were expected to attain sustainable threshold values. In Zimbabwe, there are few (or no) data available on legal limits or policy targets in potato production that could have been easily used to set indicator thresholds. Table 3 summarizes the proposed sustainability indicator thresholds.

Sustainable potato yields in the large-scale commercial and A2 resettlement systems were set at greater than 35 and $32 \mathrm{t} /$ ha respectively, mainly because these systems are mechanized and have high input levels. The average yields in the large-scale commercial and A2 resettlement systems were 23 and $19 \mathrm{t} /$ ha respectively; these were considered the unsustainable indicator thresholds for the systems. However, these growers still lag behind their counterparts in neighbouring South Africa's Sandveld area, whose average potato yield was reported as $45 \mathrm{t} / \mathrm{ha}$, with a narrow range between 36 and $58 \mathrm{t} /$ ha (Franke et al, 


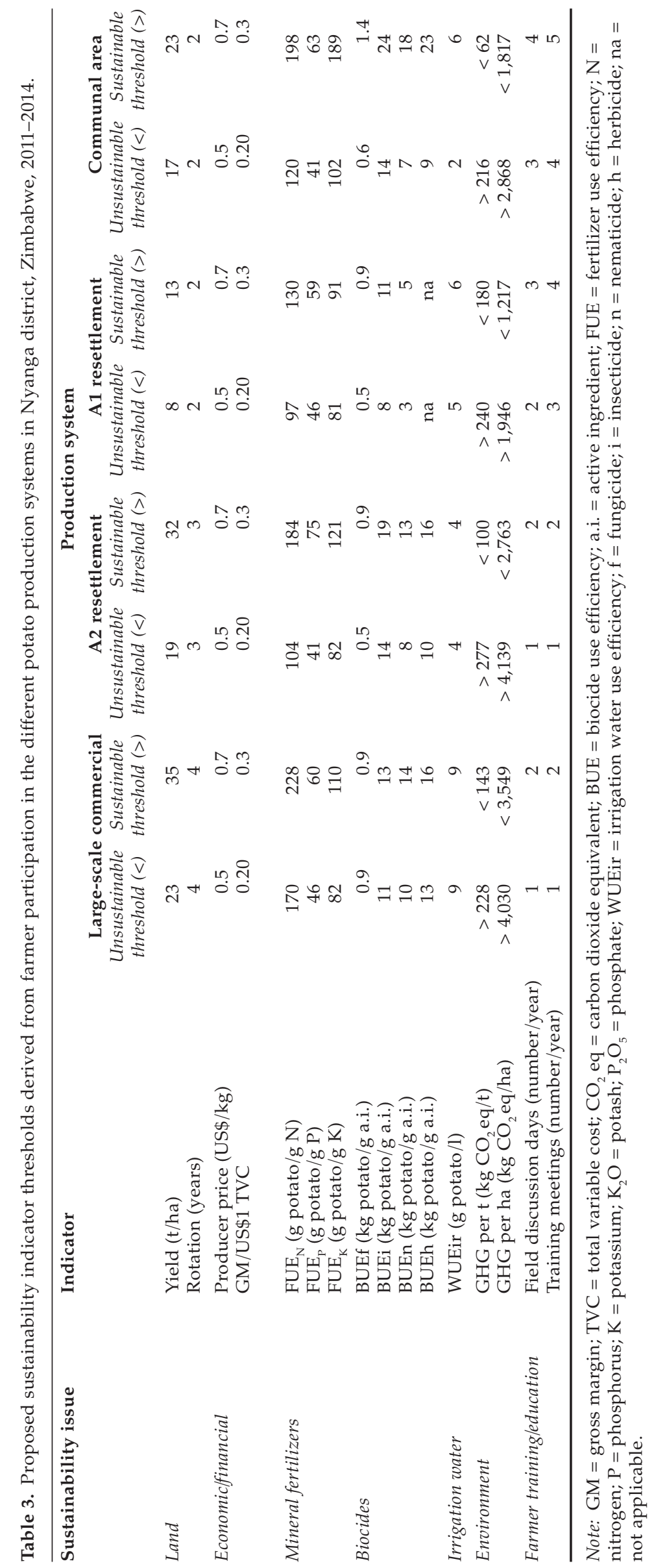


2011). Sustainable potato rotation was set at greater than two years in the smallholder A1 resettlement and communal area systems, due to constraining cropping land area (Table 2). In Zimbabwe, effective potato crop rotation excludes other solanaceous crops, and agricultural extension generally recommends one potato crop every four years on the same piece of land. The recommendation was adopted as the sustainable potato rotation in the largescale commercial and to some extent in the A2 resettlement production systems, where average cropping areas were 183 and 46 ha respectively. Unsustainable nitrogen $(\mathrm{N})$ use efficiency was set at less than 170, 120, 97 and $104 \mathrm{~g}$ of potato/g of $\mathrm{N}$ in the large-scale commercial, communal area, A1 and A2 resettlement production systems respectively (Table 3 ). These values correspond well with those reported in studies in the Sandveld area in South Africa (Franke et al, 2011), and also with those reported by Battilani et al (2008) in studies in some European countries. On biocide thresholds, the practice of integrated pest management was also recommended because of its potential to improve the biocide use efficiency through lowering biocide application rates while maintaining or even improving yields. In the A1 resettlement production system, none of the sampled farmers uses herbicides in potato production, and this is a positive practice for the environment. Herbicide use may be unnecessary during potato production in Zimbabwe because the two to three ridging operations carried out also serve as mechanical weed control measures (Svubure et al, 2015).

Sustainable irrigation water use efficiencies were set at greater than $6 \mathrm{~g}$ of potato/1 for both A1 resettlement and communal area production systems (Table 3). For the large-scale commercial and A2 resettlement systems, the sustainable irrigation water use efficiency thresholds were set at greater than 9 and $4 \mathrm{~g}$ of potato/1 respectively. These water use efficiency indicators compare very well with those reported in similar studies in the Sandveld area in South Africa (Franke et al, 2011). The large variation in GHG emissions among the sampled growers, which ranged from 62 to $479 \mathrm{~kg}$ of $\mathrm{CO}_{2} \mathrm{eq} / \mathrm{t}$, indicates that possibilities for lowering emissions exist. Sustainable GHG emissions were set using the lowest emissions in each production system (Table 3 ). On the social dimension of sustainability, higher sustainable thresholds for farmer training were set for the smallholder systems compared to the large-scale production systems, mainly because of the higher training need in the former category (Table 3). Smallholder growers are mainly dependent on the government extension agency (Agritex) for skills training and advisory services. Non-governmental organizations and agro-dealers sometimes contribute to training services for smallholder farmers. In the large-scale commercial and A2 resettlement production systems, trained agricultural workers are employed. While each system had its own set of sustainable and unsustainable threshold values, this was not the ultimate objective of sustainability. Each system should be optimized for best performance.

\section{Concluding comments}

The proposed framework, while accounting for three dimensions of sustainability, does not aggregate the sustainability indicators into a single score or composite number to evaluate a cropping system. Rather, it presents sustainable and unsustainable thresholds from which endusers (farmers) choose which indicators to target for implementation. Advantages include maintaining process transparency, easy communication of evaluation results and easy implementation, monitoring and continuous evaluation. In a similar study, van Asselt et al (2014) argued that although indicators could be quantified objectively, the overall sustainability assessment would become subjective, as it depends on the weighting or importance apportioned to each of the indicators.

The proposed framework was able to distinguish between the four different potato-based cropping systems. For example, the large-scale commercial production had higher indicator values for yield, rotation, N, P and water use efficiencies compared to the other systems. On GHG emissions, the large-scale commercial system was very competitive despite high fertilizer use and mechanization. The application of the framework showed a large variation in indicator values both between and within production systems. This suggests that farmers need to improve their performance in order to narrow the gap between the indicator values. However, a grower who chooses to improve yield to sustainable levels will inadvertently be affecting other indicators such as fertilizer, biocide and water use efficiencies.

The absence of legal limits and policy targets on many issues concerning potato production systems in Zimbabwe is a major limitation to setting sustainable indicator values. It is important to establish and publicize legal limits on such issues as groundwater extraction rates for different locations, plus permissible biocide and nutrient levels in soil, ground and surface water sources. While monitoring of farmers as they gradually improve their indicator values to sustainable levels is important, concurrent/parallel monitoring of the legal limits in the ecosystem is necessary too to ensure sustainability. The government extension agency, Agritex, is best placed to evaluate and monitor farmers' progress as they improve their threshold values towards the desired direction of sustainability. In many European countries, it is usually the industry that sets norms that are later formalized by government; industry competition then drives higher performance among its growers than the legal required minimum standard (Haverkort, personal communication, 2014).

The participatory nature of the framework is important for operationalization, monitoring and evaluation. The involvement of the farmers led to selection of indicators they viewed as important, hence incentivizing their implementation. Monitoring of farmer progression towards sustainable indicator thresholds will easily merge with the skills training and advisory services role of local agricultural extension officers.

\section{Acknowledgments}

This research was conducted under the Wageningen University and Research Centre Sandwich PhD programme, with additional funding from the Chinhoyi University of Technology for field data collection in Zimbabwe. The authors acknowledge the financial 
support from these two institutions. We express special thanks to stakeholders in the potato industry in Zimbabwe and the farmers who provided the data for this manuscript.

\section{References}

Battilani, A., Plauborg, F.L., Hansen, S., Dolezal, F., Mazurczyk, W., Bizik, J., and Coutinho, J. (2008), 'Nitrogen uptake and nitrogen use efficiency of fertigated potatoes', Acta Horticulturae, Vol 792, pp 61-67.

Breckenridge, R.P., Kepner, W.G., and Mouat, D.A. (1995), 'A process for selecting indicators for monitoring conditions of rangeland health', Environmental Monitoring and Assessment, Vol 36, pp 45-60.

Campbell, B.M., Bradley, P., and Carter, S.E. (1997), 'Sustainability and peasant farming systems: observations from Zimbabwe', Agriculture and Human Values, Vol 14, pp 159-168.

Elwell, R.H. (1984), 'Soil loss estimation: a modeling technique', in Hadley, R.F., and Walling, D.E., eds, Erosion and Sediment Yield: Some Methods of Measurement and Modelling, Geobooks, Norwich, pp 15-36.

Food and Agriculture Organization of the United Nations Statistics Division - FAOSTAT (2013), website: http://faostat3. fao.org (accessed 7 October 2014).

Franke, A.C., Steyn, J.M., Ranger, K.S., and Haverkort, A.J. (2011), ‘Developing environmental principles, criteria, indicators and norms for potato production through field surveys and modelling', Agricultural Systems, Vol 104, pp 297-306.

Fraser, E.D.G., Dougill, A.J., Mabee, W.E., Reed, M., and McAlpine, P. (2006), 'Bottom up and top down: analysis of participatory processes for sustainability indicator identification as a pathway to community empowerment and sustainable environmental management', Journal of Environmental Management, Vol 78, pp 114-127.

Gómez-Limón, J.A., and Sanchez-Fernandez, G. (2010), ‘Empirical evaluation of agricultural sustainability using composite indicators', Ecological Economics, Vol 69, No 5, pp 1062-1075.

Haverkort, A.J., Bindraban, P.S., Conijn, J.G., and de Ruijter, F.J. (2009), 'A crop production ecology (CPE) approach to sustainable production of biomass for food, feed and fuel', Outlook on Agriculture, Vol 38, No 3, pp 249-258.

Haverkort, A.J., and Hillier, J.G. (2011), ‘Cool Farm Tool - Potato: model description and performance of four production systems', Potato Research, Vol 54, pp 355-369, doi: 10.1007/ s11540-011-9194-1.

Johnson, T. (1999), 'Community based forest management in the Philippines', Journal of Forestry, Vol 97, pp 26-30.

Joyce, M.J. (1982), Some Aspects of Seed Potato Production in Zimbabwe, International Potato Course: Production, Storage, and Seed Technology, Report of Participants, International Agricultural Centre, Wageningen.

König, H.J., Sghaier, M., Schuler, J., Abdeladhim, M., Helming, K., Tonneau, J.P., Ounalli, N., Imbernon, J., Morris, J., and Wiggering, H. (2012), ‘Participatory impact assessment of soil and water conservation scenarios in Oum Zessar Watershed, Tunisia', Environmental Management, Vol 50, pp 153-165.

Mascarenhasa, A., Nunesb, L.M., and Ramos, T.B. (2014), 'Exploring the self-assessment of sustainability indicators by different stakeholders', Ecological Indicators, Vol 39, pp 75-83.

Moyo, S. (2011), 'Three decades of land reform in Zimbabwe', Journal of Peasant Studies, Vol 38, No 3, pp 493-571.

Pannell, D.J., and Glenn, N.A. (2000), 'A framework for the economic evaluation and selection of sustainability indicators in agriculture', Ecological Economics, Vol 33, No 1, pp 135-149.

Paracchini, M.L., Pacini, C., Jones, M.L.M., and Perez-Soba, M. (2011), 'An aggregation framework to link indicators associated with multifunctional land use to the stakeholder evaluation of policy options', Ecological Indicators, Vol 11, pp 71-80.

Patterson, M. (2006), 'Selecting headline indicators for tracking progress to sustainability in a nation state', in Lawn, P., ed,
Sustainable Development Indicators in Ecological Economics, Edward Elgar, Cheltenham, pp 421-448.

Pope, J., Annandale, D., and Morrison-Saunders, A. (2004), 'Conceptualising sustainability assessment', Environmental Impact Assessment Review, Vol 24, pp 595-616, doi: 10.1016/ j.eiar.2004.03.001.

Pretty, J. (2007), 'Agricultural sustainability: concepts, principles and evidence', Philosophical Transactions of the Royal Society B, Vol 363, pp 447-465.

Ramos, T.B., and Caeiro, S. (2010), 'Meta-performance evaluation of sustainability indicators', Ecological Indicators, Vol 10, pp 157166.

Reed, M.S., and Dougill, A.J. (2002), 'Participatory selection process for indicators of rangeland condition in the Kalahari', The Geographical Journal, Vol 168, No 3, pp 224-234.

Reidsma, P., König, H., Feng, S., Bezlepkina, I., Nesheim, I., Bonin, M., Sghaier, M., Purushothaman, S., Sieber, S., Van Ittersum, M.K., and Brouwer, F. (2011), 'Methods and tools for integrated assessment of land use policies on sustainable development in developing countries', Land Use Policy, Vol 28 , pp 604-617.

Ritchie, J., and Lewis, J., eds (2012 [2003]), Qualitative Research Practice: A Guide for Social Science Students and Researchers, Sage Publications, London, ISBN: 978-0-7619-7109-2c.

Roy, R., and Chan, N.W. (2012), 'An assessment of agricultural sustainability indicators in Bangladesh: review and synthesis', Environmentalist, Vol 32, pp 99-110.

Saisana, M., and Tarantola, S. (2002), State-of-the-art Report on Current Methodologies and Practices for Composite Indicator Development, EUR 20408 EN, European Commission-JRC, Ispra, Italy.

Santana-Medina, N., Franco-Maass, S., Sanchez-Vera, E., Imbernon, J., and Nava-Bernal, G. (2013), ‘Participatory generation of sustainability indicators in a natural protected area of Mexico', Ecological Indicators, Vol 25, pp 1-9, doi: 10.1016/j.ecolind.2012.09.002.

Svubure, O., Struik, P.C., Haverkort, A.J., and Steyn, J.M. (2015), 'Yield gap analysis and resource footprints of Irish potato production systems in Zimbabwe', Field Crops Research, Vol 178, pp 77-90.

Swift, M.J., and Woomer, P. (1993), 'Organic matter and the sustainability of agricultural systems: definition and measurement', in Mulongoy, K., and Merckx, R., eds, Soil Organic Matter Dynamics and Sustainability of Tropical Agriculture, Wiley, Chichester, pp 3-18.

The Herald (2011), 'Potato: hidden treasure crop', 25 June, website: http://maravi.blogspot.nl/2011/07/herald-potato-h-iddentreasure-crop.html (accessed 27 February 2015).

The Herald (2012), 'Potato declared strategic food security crop', 18 May, website: http://www.herald.co.zw/potato-declaredstrategic-food-security-crop/ (accessed 23 July 2013).

Vaidya, A., and Mayer, A.L. (2014), 'Use of the participatory approach to develop sustainability assessments for natural resource management', International Journal of Sustainable Development $\mathcal{E}$ World Ecology, Vol 21, No 4, pp 369-379, doi: $10.1080 / 13504509.2013 .868376$

van Asselt, E.D., van Bussel, L.G.J., van der Voet, H., van der Heijden, G.W.A.M., Tromp, S.O., Rijgersberg, H., van Evert, F., van Wagenberg, C.P.A., and van der Fels-Klerx, H.J. (2014), 'A protocol for evaluating the sustainability of agri-food production systems - a case study on potato production in peri-urban agriculture in The Netherlands', Ecological Indicators, Vol 43, pp 35-321.

Waddington, S.R., Mekuria, M., Siziba, S., and Karigwindi, J. (2007), 'Long-term yield sustainability and financial returns from grain legume-maize intercrops on a sandy soil in sub humid north central Zimbabwe', Experimental Agriculture, Vol 43, pp 489-503.

Yegbemey, R.N., Yabi, J.A., Dossa, C.S.G., and Bauer, S. (2014), 'Novel participatory indicators of sustainability reveal weaknesses of maize cropping in Benin', Agronomy for Sustainable Development, Vol 34, pp 909-920. 